Arkhais, Vol. 06 No. 2 Jufi - Desember 2015

\title{
DISFEMIA DALAM RUBRIK OLIMPIK DI HARIAN BOLA
}

\author{
Nugroho Sejati
}

\begin{abstract}
Abstrak. Tujuan penelitian ini adalah untuk mengetahui penggunaan disfemia dalam berita olahraga, khususnya pada media massa cetak. Penelitian ini juga untuk mengetahui frekuensi penggunaan disfemia berdasarkan bentuk kebahasaannya maupun fungsinya. Metode yang digunakan dalam penelitian ini adalah metode deskriptif dengan analisis isi. Penelitian ini dilaksanakan dari bulan Januari sampai bulan November 2014. Fokus penelitian ini adalah penggunaan disfemia pada rubrik Olimpik di Harian BOLA, meliputi bentuk dan fungsinya. Instrumen penelitian ini adalah peneliti sendiri dibantu dengan tabel kerja analisis. Berdasarkan hasil penelitian tersebut bahwa bentuk-bentuk kebahasaan yang ditampilkan dalam rubrik Olimpik di Harian BOLA cukup bervariasi. Dalam penelitian ini, bentuk kata dan fungsi menarik perhatian paling banyak ditemukan.
\end{abstract}

Kata Kunci: Disfemia, Rubrik Olimpik Harian BOLA

\section{PENDAHULUAN}

Dalam penggunaan bahasa sehari-hari, masyarakat memiliki berbagai keperluan. Salah satunya untuk menyampaikan pikiran dan perasan dengan tepat. Misalnya, untuk mengungkapkan rasa senang, sedih, marah, atau kecewa. Selain itu, penggunaan bahasa juga dapat dimaksudnya untuk menyindir, mengejek, atau menarik perhatian. Keperluankeperluan dalam menggunakan bahasa tersebut membuat munculnya gaya bahasa. Gaya atau khususnya gaya bahasa dikenal dalam retorika dengan istilah style. Karena perkembangan itu, gaya bahasa atau style menjadi masalah atau bagian dari diksi atau pilihan kata yang mempersoalkan cocok tidaknya pemakaian kata, frasa, atau klausa tertentu untuk menghadapi situasi tertentu. Sebab itu, persoalan gaya bahasa meliputi semua hirarki kebahasaan: pilihan kata secara individual, frasa, klausa, dan kalimat, bahkan mencakup pula sebuah wacana termasuk pula persoalan gaya bahasa. Bila kita melihat gaya secara umum, kita dapat mengatakan bahwa gaya adalah cara mengungkapkan diri sendiri, entah melalui bahasa, tingkah laku, berpakaian, dan sebagainya. Dilihat dari segi bahasa, gaya bahasa adalah cara menggunakan bahasa.

Gaya bahasa berkaitan dengan ragam bahasa. Bahasa memiliki berbagai macam ragam. Salah satunya adalah ragam bahasa jurnalistik. Pada ragam bahasa jurnalistik sering ditemukan penggunaan „nilai rasa"e. Bahasa jurnalistik banyak menggunakan kata-kata atau istilah-istilah yang banyak memiliki nilai rasa atau yang bersifat ikonis. Dengan memakai bentuk-bentuk bernilai rasa yang demikian itu, bahasa ragam jurnalistik tidak akan terlampau kaku dan membosankan. Berdasarkan bentuknya, jurnalistik atau media massa terbagi menjadi dua, yaitu media massa elektronik dan media massa cetak. Media massa elektronik meliputi televisi, radio, internet, dan sebagainya. Media massa cetak meliputi surat kabar harian, majalah, tabloid, dan media cetak lainnya yang bersifat umum untuk menyampaikan pikiran, perasaan, dan gagasan seseorang atau badan tertentu. Penyampaian pikiran, perasaan, dan gagasan tertentu dituangkan menjadi berita yang bertujuan untuk memberitahukan sesuatu hal tertentu. Media massa merupakan salah satu alat pendidikan masyarakat. Masyarakat menilai media massa telah berusaha menggunakan bahasa yang baik, sesuai dengan tuntutan jurnalistik agar menarik. Oleh karena itu, media massa kerap menggunakan kata-kata, frasa-frasa, klausa-klausa, serta kalimat-kalimat yang memiliki nilai rasa tertentu. 
Terdapat gaya bahasa yang khas pada ragam jurnalistik di media massa, khususnya media massa olahraga. Berdasarkan pilihan kata, gaya bahasa mempersoalkan kata mana yang tepat dan sesuai untuk posisi tertentu dalam kalimat, serta tepat tidaknya penggunaan kata-kata dilihat dari lapisan pemakaian bahasa dalam masyarakat. Dengan kata lain, gaya bahasa ini mempersoalkan ketepatan dan kesesuaian dalam menghadapi situasi-situasi tertentu. Hal-hal seperti itu banyak ditemui dalam media olahraga. Bahasa ragam jurnalistik juga sangat mengedepankan disfemia atau pengasaran makna. Karena alasan yang amat mendasar itulah, di antaranya, maka bahasa ragam jurnalistik cenderung untuk menghindari bentuk-bentuk pasif, bentuk santun, dan bentuk eufimistis. Sikap kritis seorang jurnalis akan cepat memudar ketika prinsip bahasa jurnalistik yang harus ringkas dan lugas, malah dibuat menjadi samar dan meliuk-liuk. Lawan makna dari eufemisme adalah disfemia. Disfemia adalah upaya untuk mengganti kata-kata atau ungkapan biasa atau halus dengan kata-kata atau ungkapan yang terasa kasar. Disfemia banyak ditemukan dalam berita-berita di media massa, khususnya media massa cetak, terutama pada berita olahraga karena olahraga merupakan salah satu hal paling universal di dunia yang kerap menguras emosi dari para pelaku dan penikmatnya. Contoh penggunaan disfemia dalam berita olahraga ditemukan pada kalimat:

"Pada ganda putra, duet Fran Kurniawan/Bona Septano (Djarum/Jaya Raya) menjadi yang terbaik setelah menggusur Hafiz Faisal/Putra Eka Rhoma (Jaya Raya), 22-20, 21-17."

Kata menggusur dianggap bernilai rasa kurang baik. Makna leksikal dari menggusur adalah menjadikan (membuat, menyuruh) pindah tempat; menggeser tempat, namun bila dilihat dalam konteks kalimat, makna menggusur berarti mengalahkan. Penggunaan disfemia melalui kata menggusur bertujuan untuk menarik perhatian pembaca. Saat ini, media massa cetak mulai tersaingi dengan media massa elektronik. Masyarakat lebih mudah dan murah mendapat berita melalui jaringan internet daripada harus membeli koran atau majalah. Oleh sebab itu, media massa cetak lebih memperkuat konten berita dan membuat judul atau gaya bahasa yang lebih menarik. Berdasarkan keterangan di atas, dalam penelitian ini, penulis mencoba menganalisis penggunaan disfemia dalam berita olahraga. Penulis memilih rubrik Olimpik di HarianBOLA sebagai sampel penelitian karena Harian BOLA merupakan media olahraga pelopordan terbesar di Indonesia.

\section{HASIL DAN PEMBAHASAN}

Bahasa dapat ditinjau dari bermacam-macam sudut pandang. Oleh sebab itu, sulitdiperoleh kata sepakat mengenai suatu pembagian yang bersifat menyeluruh dan dapat diterima oleh semua pihak. Pandangan-pandangan atau pendapat tentang gaya bahasa sejauh ini dapat dibedakan menjadi dua yaitu dilihat dari segi nonbahasa, dan kedua, dari segi bahasanya sendiri. Untuk memberi pengetahuan dan keterampilan, maka mengenai gaya dilihat dari aspek kebahasaan akan lebih diperlukan.Penggunaan gaya bahasa pada seseorang memungkinkan orang lain dapat menilai pribadi, watak, dan kemampuan seseorang yang menggunakan bahasa itu. Semakin baik bahasanya, maka semakin baik pula penilaian orang terhadapnya. Semakin buruk bahasanya, maka semakin buruk pula orang menilainya.Selain itu, gaya bahasa dibatasi sebagai cara mengungkapkan pikiran melalui bahasa secara khas yang memperlihatkan jiwa dan kepribadian penulis atau pembicara. Gaya bahasa seseorang pada saat mengungkapkan perasaannya, baik secara lisan maupun tulisan dapat menimbulkan reaksi pembaca atau pendengar berupa tanggapan.

Secara leksikologis yang dimaksud dengan gaya bahasa, yakni: (i) pemanfaatan atas kekayaan bahasa oleh seseorang dalam bertutur atau menulis; (ii) pemakaian ragam tertentu untuk memperoleh efek-efek tertentu; (iii) keseluruhan ciri bahasa sekelompok 
penulis sastra; (iv) cara khas dalam menyatakan pikiran dan perasaan dalam bentuk tulisa atau lisan.Berdasarkan uraian di atas, gaya bahasa dapat diartikan sebagai ujaran atau tulisan yang disajikan dengan cara yang menarik perhatian dan minat para pendengar atau pembacanya. Dengan kata lain, gaya bahasa itu adalah cara penyajian ujaran atau tulisan yang sengaja memikat perhatian pendengar atau pembacanya, untuk tetap menekuninya.Orang masih sering terkecoh dengan istilah gaya bahasa. Mereka hanya mengganggap gaya bahasa hanya meliputi pembentukan kalimat yang memperlihatkan corak-corak tertentu. Padahal persoalan gaya ini meliputi semua hierarki kebahasaan: mulai dari diksi, frasa, kalimat, hingga wacana. Dengan gaya bahasa, pertanyaanpertanyaan atau ekspresi menjadi lebih konkret, lebih jelas, dan lebih hidup daripada jika ekspresi itu dinyatakan dengan leteral saja. Di samping itu, pembaca atau pendengar juga menjadi lebih tergugah.

Gaya bahasa menurut Slametmuljana adalah susunan perkataan yang terjadi karena perasaan yang timbul atau hidup dalam hati penulis, yang menimbulkan suatu perasaan tertentu dalam hati pembaca. Gaya bahasa disebut majas. Gaya bahasa seseorang pada saat mengungkapkan perasaannya, baik seara lisan maupun tulisan dapat menimbulkan reaksi pembaca berupa tanggapan. Secara garis besar, gaya bahasa terdiri atas empat jenis, yaitu majas penegasan, majas pertentangan, majas perbandingan, dan majas sindiran.Majas penegasan adalah gaya bahasa untuk menegaskan sesuatu dengan cara seolah-olah menyangkal hal yang ditegaskan. Majas pertentangan adalah gaya bahasa yang mengungkapkan suatu maksud dengan menggunakan kata-kata saling berlawanan. Majas perbandingan adalah gaya bahasa yang membandingkan dua hal benda secara singkat dan padat. Sedangkan yang terakhir adalah majas sindiran. Majas sindirian adalah gaya bahasa untuk mengatakan suatu maksud menggunakan kata-kata yang berlainan atau bertolak belakang dengan maksud tersebut. Menurut Charles H. Vivian dan Bernetta M. Jackson itu gaya bahasa dapat dikelompokkan dalam tiga kategori, yaitu: gaya bahasa perbandingan, gaya bahasa pengontrasan, dan gaya bahasa asosiasi. Gaya bahasa perbandingan ialah membandingkan dua hal benda secara singkat dan padat itu meliputi simile, metafor, dan personifikasi. Gaya bahasa pengontrasan adalah perbedaan antara apa yang dikatakan dengan apa yang dimaksud yang meliputi ironi, hiperbol, dan litotes. Sedangkan gaya bahasa asosiasi adalah sebuah kata diperluas atau diperkecil untuk mewakili suatu keseluruhan atau keseluruhan yang meliputi metonimi dan sinekdot.

Dasar untuk menciptakan gaya bahasa dalam kalimat-kalimat yang kita pergunakan dan titik tolak itu adalah struktur kalimat, penyimpangan makna kalimat untuk mencapai efek, penyimpangan makna kalimat untuk memperoleh makna kias. Pengungkapan pikiran dengan gaya bahasa yang tegas dan lugas juga mewarnai perkembangan lainnya dalam ragam tulis maupun ragam lisan. Semua perubahan ini tidak lepas dari bahasa sebagai unsur budaya yang mencerminkan perilaku masyarakat pemakainya yang dipengaruhi oleh faktor sosial, politik, ekonomi, hukum, dan sebagainya.Bila gaya dilihat secara umum, dapat dikatakan bahwa gaya adalah cara mengungkapkan diri sendiri. gaya bahasa memungkinkan seseorang dapat menilai pribadi, watak, dan kemampuan orang lain yang mempergunakan bahasa itu. Terdapat berbagai macam gaya bahasa, salah satunya yang berkaitan dengan nilai rasa adalah disfemia.Dalam komunikasi sehari-hari, kita tidak hanya mengenal satu cara untuk menyampaikan suatu maksud. Cara-cara yang digunakan bergantung pada masing-masing pribadi yang menggunakannya. Karena pribadi setiap orang berbeda-beda, maka berbeda-beda pula cara penyampaian maksudnya itu.

Dalam kehidupan sehari-hari ada kata-kata yang halus dan sopan untuk digunakan dan ada juga kata-kata yang tidak boleh digunakan pada situasi tertentu karena dirasakan kasar atau kurang sopan untuk digunakan dalam berkomunikasi. Kata-kata tersebut 
digunakan sebagai suatu sindiran terhadap sesuatu atau seseorang. Hal ini tidak hanya terjadi saat komunikasi antara orang yang satu dengan orang lain secara langsung.Majalah dan koran walaupun menyajikan berita dan peristiwa menggunakan banyak kata-kata bernuansa negatif, tetapi gaya bahasanya masih dinilai sopan dan baku. Menjelang kejatuhan Presiden Suharto sampai 3-4 tahun berikutnya tampak terjadi perkembangan dalam bahasa Indonesia, terutama di bidang leksikon dan gaya bahasa. Perkembangan ini tidak ditandai oleh munculnya kata-kata baru, tetapi digunakan kembali kata-kata bercitra negatif yang sebelumnya jarang atau bahkan tidak digunakan, hal tersebut adalah salah satu contoh disfemia.Pada dasarnya penggunaan disfemia terdapat dalam segala jenis macam bahasa. Disfemia adalah kebalikan dari eufemia. Kalau eufemia merupakan upaya untuk menghindarkan ketidaksopanan atau kekasaran dengan kata-kata atau ungkapan halus, maka disfemia adalah upaya untuk mengganti kata-kata atau ungkapan biasa atau halus dengan kata-kata atau ungkapan yang terasa kasar. Buku Pengantar Semantik Bahasa Indonesia juga menjelaskan bahwa disfemia yaitu usaha untuk mengganti kata-kata yang maknanya halus atau bermakna biasa dengan kata-kata yang maknanya kasar, usaha pengasaran ini biasanya dilakukan dalam situasi yang tidak ramah. Selain itu, disfemia digunakan orang dalam situasi untuk menyatakan sindiran, kejengkelan, ataupun untuk menarik perhatian orang lain. Contoh penggunaan disfemia yang menyatakan ejekan ditemukan pada kalimat:

"Pada ganda putra, duet Fran Kurniawan/Bona Septano (Djarum/Jaya Raya) menjadi yang terbaik setelah menggusur Hafiz Faisal/Putra Eka Rhoma (Jaya Raya), 22-20, 21-17."

Kata menggusur dianggap bernilai rasa kurang baik. Makna leksikal dari menggusur adalah menjadikan (membuat, menyuruh) pindah tempat; menggeser tempat, namun bila dilihat dalam konteks kalimat, makna menggusur berarti mengalahkan. Penggunaan disfemia melalui kata menggusur bertujuan untuk menarik perhatian pembaca. Menurut ensiklopedia sastra, disfemia adalah gaya bahasa yang sengaja menggunakan kata-kata yang mengandung makna lebih tajam untuk menimbulkan rasa simpati bagi pendengarnya. Slamet Mulyana juga berpendapat bahwa disfemia adalah ungkapan kasar, bahkan ada yang menyebutnya sebagai olok-olok. Sering pula sesuatu perkataan selain daripada mengandung sesuatu arti, mengandung pula sesuatu perasaan, yaitu apabila kita mendengar atau membacanya pada kita timbul beberapa perasaan tertentu. Nilai perasaan sesuatu perkataan itu bergantung kepada perbedaan paham antara seseorang dengan yang lain. Nilai perasaan itu sering dipakai dalam berbagai cara melakukan sesuatu yaitu pada disfemia yaitu ungkapan yang terasa kasar.

Ada beberapa ungkapan yang sifatnya memperkasar perasaan. Misalnya, sering dikatakan bahwa kata mati sama maknanya dengan kata meninggal. Menurut teori semantik, kata mati tidak sama maknanya dengan kata meninggal. Sebab, jika kedua kata itu sama maknanya, tentu keduanya dapat dipertukarkan secara bebas. Pada kenyataannya kedua kata itu tidak bisa dipertukarkan secara bebas. Usaha atau gejala pengasaran ini biasanya dilakukan orang dalam situasi yang tidak ramah atau menunjukkan kejengkelan. Misalnya, kata mendepak yang dipakai untuk mengganti kata mengeluarkan seperti pada kalimat, "Setelah berkuasa, ia segera mendepak orang-orang yang tidak disukainya." Disfemia berkaitan dengan nilai rasa, sama halnya dengan eufemia. Jika eufemia menimbulkan nilai rasa yang baik, disfemia menimbulkan nilai rasa yang buruk atau kurang baik, meskipun tidak semua penggunaan disfemia dimaksudkan untuk menimbulkan kesan yang kurang baik. Penggunaan disfemia terkadang sebagai alat untuk menciptakan suatu percakapan yang menarik. Begitupun di kalangan jurnalis, penggunaan 
disfemia dimaksudkan untuk menarik perhatian agar informasi atau pesan yang ingin disampaikan sebagai sesuatu yang serius dan formal.

Penyebab digunakannya disfemia adalah sebagai sindiran, ejekan, ataupun untuk menarik perhatian juga untuk memberi tekanan pada makna kata yang digunakan tanpa terasa kekasarannya. Disfemia merupakan pernyataan kasar atau ungkapan kasar. Oleh karena itu, peneliti juga mengkaji berdasarkan bentuk kebahasaannya. Disfemia berbentuk kata misalnya melibas yang merupakan bentuk pengasaran dari mengalahkan. Kemudian, disfemia bisaberupa frasa, seperti frasa biang keladi yang merupakan bentuk pengasaran dari kata penyebab. Disfemia ini digunakan orang dalam situasi yang tidak ramah, untuk menyatakan kejengkelan, ataupun untuk lebih menarik perhatian pembaca atau pendengar. Dalam kehidupan sehari-hari, untuk menarik perhatian, banyak upaya disfemia ini dilakukan orang, baik dalam percakapan biasa maupun dalam berita-berita media massa. Misalnya, "memasukkan ke dalam penjara" didisfemiakan menjadi "menjebloskan ke dalam penjara".

Disfemia itu sendiri termasuk dalam majas perbandingan karena gaya bahasa yang menggunakan kata-kata kasar untuk mengganti kata-kata atau ungkapan yang terasa halus. Disfemia tersebut termasuk dalam gaya bahasa, karena perkembangan itu, gaya bahasa menjadi masalah atau bagian dari diksi atau yang mempersoalkan cocok tidaknya pemakaian kata, frasa, atau klausa tertentu untuk menghadapi situasi tertentu. Sebab itu, persoalan gaya bahasa meliputi semua hierarki kebahasaan. Kata adalah deretan huruf yang diapit oleh dua buah spasi dan mempunyai satu arti. Kata terdiri atas kata dasar, kata berimbuhan, kata berulang, maupun bentuk majemuk.

Frasa adalah satuan gramatikal yang berupa gabungan kata yang bersifat nonpredikatif, atau gabungan kata yang mengisi salah satu fungsi sintaksis di dalam kalimat. Klausa adalah satuan sintaksis yang terdiri atas dua kata atau lebih yang mengandung unsur predikasi. Kalimat adalah satuan bahasa terkecil, dalam wujud lisan atau tulisan yang mengungkapkan pikiran yang utuh. Dari uraian di atas dapat disimpulkan bahwa disfemia adalah upaya mengganti kata atau ungkapan yang maknanya biasa dan cenderung halus dengan kata yang maknanya lebih kasar. Disfemia digunakan sebagai sindiran yaitu perkataan atau gambar yang bermaksud menyindir orang, digunakan sebagai ejekan yaitu perbuatan mengejek, digunakan juga untuk menarik perhatian, yaitu menunjukkan kejengkelan ataupun untuk lebih memberi tekanan pada makna kata yang digunakan tanpa terasa kekasarannya.

\section{KESIMPULAN}

Berdasarkan hasil analisis yang telah disajikan, maka dapat ditarik kesimpulan sebagai berikut. Berdasarkan penelitian yang telah dilakukan, dapat disimpulkan bahwa dari sampel berita olahraga dalam rubrik Olimpik di Harian BOLA ditemukan 420 disfemia. Hasil analisis memperlihatkan bahwa disfemia bentuk kata memiliki frekuensi tertinggi. Disfemia bentuk kata berjumlah sebanyak 384 kata, sedangkan disfemia yang berbentuk frasa sebanyak 27 frasa, dan yang berbentuk klausa sebanyak 9 klausa. Hal ini berarti bahwa rubrik Olimpik Harian BOLA cenderung menggunakan bentuk kata untuk mengungkapkan disfemia dibandingkan bentuk-bentuk lainnya. Ini menunjukkan bentuk kata lebih mudah digunakan dan dipahami untuk menyampaikan suatu hal yang mengandung disfemia di Harian BOLA.

Berdasarkan fungsinya, terdapat 75 disfemia yang berfungsi sebagai sindiran, 120 disfemia yang berfungsi sebagai ejekan, lalu 225 difemia yang dimaksudkan untuk menarik perhatian. Hal ini berarti bahwa penggunaan disfemia di Harian BOLA lebih banyak dimaksudkan untuk menarik perhatian pembaca. Dilihat dari bentuk yang digunakan pada fungsi tertentu dalam disfemia yang terdapat dalam rubrik Olimpik di 
Harian BOLA, maka bentuk kata paling banyak digunakan baik pada fungsi sindiran, ejekan, maupun menarik perhatian. Demi kemajuan ilmu pengetahuan, peneliti berharap hasil penelitian ini dapat merangsang peneliti lain untuk meneliti disfemia dari berbagai sudut dan lebih mendalam serta dengan objek kajian yang lebih relevan dengan perkembangan zaman. Peneliti juga berharap hasil penelitian ini bermanfaat bagi masyarakat bisa dalam memahami dalam penggunakan disfemia dari segi bentuk kebahasaaan dan fungsinya serta dapat menerapkan disfemia dengan tepat, sehingga masyarakat dapat berpikir kritis terhadap penggunaan disfemia untuk komunikasi menjadi lebih "nyaman" dan saling menghormati serta terjadi kerja sama yang baik.

\section{DAFTAR RUJUKAN}

Alisjahbana, S. Takdir. 1986. Tata Bahasa Baru Bahasa Indonesia. Jakarta: Dian Rakyat.

Alwi, Hasan dkk. 2003. Tata Bahasa Baku Bahasa Indonesia. Jakarta: Balai Pustaka.

Bungin, Burhan. 2008. Metodologi Penelitian Kualitatif. Jakarta: Raja Grafindo Persada. Chaer, Abdul. 2003. Seputar Tata Bahasa Baku Bahasa Indonesia. Jakarta: Rineka Cipta. . 2007. Linguistik Umum. Jakarta: Rineka Cipta. . 2007. Leksikologi dan Leksikografi. Jakarta: Rineka Cipta. . 2009. Pengantar Semantik Bahasa Indonesia. Jakarta: Rineka Cipta.

Efendi, Onong Uchjana. 1993. Ilmu, Teori, dan Filsafat Komunikas. Bandung: Citra Aditya Bakti.

Fadjar, Malik A. 2004. Ensiklopedia Sastra Indonesia. Bandung: Titian Ilmu.

Kari, Syarifudin dkk.. 1986. Bahasa Indonesia dalam Ragam dan Gaya. Bukittinggi: Indah.

Keraf, Gorys. 2006. Diksi dan Gaya Bahasa. Jakarta: PT Gramedia Pustaka Utama.

Mahsun. 2007. Metode Penelitian Bahasa. Jakarta: Raja Grafindo.

Mulyana, Slamet. 1964. Semantik. Jakarta: Djambatan.

Pateda, Mansoer. 2002. Semantik Leksikal. Jakarta: Rineka Cipta. Rahardi, Kunjana. 2011. Bahasa Jurnalistik. Bogor: Ghalia Indonesia.

Sudjiman, Panuti. 1984. Kamus Istilah Sastra. Jakarta: Gramedia.

Sugono, Dendy dkk.. 2009. Kamus Besar Bahasa Indonesia. Jakarta: Balai Pustaka.

Sumadiria, Haris. 2010. Bahasa Jurnalistik. Bandung: Simbiosa Rekatama Media

Waridah, Ernawati. 2010. EYD Seputar Kebahasa-Indonesiaan. Jakarta: Kawan Pustaka.

Wasito, Hermawan. 1995. Pengantar Metodologi Penelitian. Jakarta: PT. Gramedia PustakaUtama.

Wibowo, Wahyu. 2001. Manajemen Bahasa. Jakarta: PT Gramedia Pustaka Utama

Widjono Hs.. 2007. Bahasa Indonesia. Jakarta: Grasindo http://www.wikipedia.org/ tabloid-bola.html (diakses pada tanggal 12 November 2014 pukul21.30). 